International Journal of Environment, Agriculture and Biotechnology
Vol-6, Issue-6; Nov-Dec, 2021
Jurnal Home Page Available: $\underline{\text { https://ijeab.com/ }}$
Journal DOI: $\underline{10.22161 / \text { ijeab }}$

\title{
Plant formations of Pterocarpus erinaceus Poir. in Sudanian and Sahelian zones
}

\author{
Habou Rabiou ${ }^{1 *}$, Issiaka Issaharou-Matchi ${ }^{2}$, Kossi Adjonou $^{3}$, Kossi Novinyo Segla ${ }^{3}$, \\ Babou André Bationo ${ }^{4}$, Kouami Kokou ${ }^{3}$, Ali Mahamane ${ }^{1}$
}

\author{
${ }^{1}$ Faculty of Agronomic Sciences, University of Diffa, BP 78 Diffa, Niger \\ ${ }^{2}$ Higher Institute for Environment and Ecology (IS2E), University of Diffa, BP 78 Diffa, Niger \\ ${ }^{3}$ University of Lomé, Faculty of Sciences, BP 1515, Lomé, Togo; \\ ${ }^{4}$ Institute for the Environment and Agricultural Research (INERA), 04 BP 8645 Ouagadougou 04, Burkina Faso; \\ Corresponding author: rabiouhabougarba@yahoo.fr
}

\begin{abstract}
Received: 21 Sep 2021; Received in revised form: 06 Nov 2021; Accepted: 15 Nov 2021; Available online: 22 Nov 2021 C2021 The Author(s). Published by Infogain Publication. This is an open access article under the CC BY license (https://creativecommons.org/licenses/by/4.0/).
\end{abstract}

\begin{abstract}
In the Sudano-Sahelian zones of West Africa, climate controls the distribution and composition of spontaneous vegetation. The study was conducted in Niger and Burkina Faso. It aims to (1) analyze the ecological and floristic characteristics in a heterogeneous environment of 8 forests: (2) determine the woody groups of plant formations in P. erinaceus along an agroecological gradient. A total of 206 plots of $1000 \mathrm{~m}^{2}$ were established in 8 forests along an agroecological gradient in Niger and Burkina Faso. In each plot, dendrometric measurements such as DBH, Total height and two perpendicular diameters of the crown were performed on all woody individuals of all recorded species with $\mathrm{DBH}>5 \mathrm{~cm}$. Our study identified 117 species belonging to 25 families. The four most represented families are Fabaceae (31.8\%), Combretaceae (16.8\%), Malvaceae (7.9\%) and Rubiaceae (6.9\%). Our results revealed that Microphanerophytes is the dominating biological type in all forests. The Shannon index shows that the species richness and diversity increase with increasing humidity from the Sahelian to the Sudano-Guinean zone. Sorensen's index shows that the similarity is greater between the forests of Tiogo, Cassou and Laba in Burkina Faso. The Ascending Hierarchical Classification and the Non-Multidimensional Scaling made it possible to determine six large groupings of $P$. erinaceus. We conclude that $P$. erinaceus has great ecological amplitude and its distribution zone extends from the Sahelian to the Guinean zones while associating with a diversity of plant species.
\end{abstract}

Keywords-Plant formations, vegetation, Shannon index, agroecological gradient.

\section{INTRODUCTION}

In Sudano-Sahelian zones of West Africa, the distribution, composition and structure of spontaneous vegetation depend on climate, soil, anthropogenic activities, herbivores and fire (Osborne et al., 2018; Coulibaly et al., 2019). The ecosystems have arguably been shaped by humans for thousands of years (Pennington et al., 2015). The interaction between anthropogenic, abiotic and biotic factors makes it difficult to identify and quantify the main determinants of plant association (Stevens et al., 2016). Tropical savannahs are habitat to many species and are among the richest ecosystems of the world (Loubota et al., 2018a; Ouédraogo et al., 2018). This characteristic is the most important challenge for understanding their functioning. The multiple interactions between species and with their environment make these forests extremely complex ecosystems (Loubota et al., 2018a). The heterogeneity of these environments, due to a pronounced rainfall gradient, influences the structure, composition and distribution of the characteristic species. The work of Osborne et al. (2018) indicated that the unique combinations of functional characteristics of plants characterizing the main associations of African savannahs make them differentially vulnerable and resilient to anthropogenic factors of ecosystem change. 
Among the plants currently very exploited, we note $P$. erinaceus whose quality of wood, makes this species very sought after. This species is also exploited for various purposes such as fodder and various medicinal products etc. In addition, changes in land use patterns and their consequences on ecosystems have been recognized as a major component of global changes, of comparable significance to climatic and atmospheric variations (Mahamane et al., 2007). Given this complexity, one of the approaches adopted is the study of the dynamics of the species studied, chosen for their commercial and/or ecological interest. The set of inter-fertile individuals is considered a population, for the natural need of association, the populations of a given species cohabit with populations of other species evolving in the same natural environment. An association is a plant group characterized by a floristically determined and relatively constant composition within the limits of a given area (Solefacka, 2018). Any association represents a more or less stable stage of more or less long duration in a progressive or regressive series of association. The overexploitation of some species with great socio-economic values is one of the destabilizing factors of the plant association, especially in the Sahelian and Sudanian zones of West Africa.

Numerous studies have shown that woody species reflect better the variation of environmental factors (Chen et al., 2016; Mahamane et al., 2007; Loubota et al., 2018b) and represent the best indicators for assessing climatic and environmental variability (Thiombiano et al., 2006 ; Ligot et al., 2018; Gaisberger et al., 2017). According to Chen et al. (2016), the composition and structure of woody vegetation vary considerably from one agro-ecological zone to another. But African savannahs are considerably being modified by anthropogenic activities (Osborne et al., 2018). The present study seeks to 1 ) analyse the ecological and floristic characteristics in a heterogeneous environment of 8 forests; 2) determine the woody groups of $P$. erinaceus plant formations along agroecological gradient in Niger and Burkina Faso.

\section{MATERIAL AND METHODS}

\section{Study sites}

In this study we surveyed four (4) agroecological zones from North to South which are Sahelo-Sudanian and North Sudanian zones in Niger and South Sudanian and Sudanese-Guinean zones (Burkina Faso). In each area, representative forests were identified and investigated. The climatic characteristics and the geographical position of each site are summarized in Table 1.

In Niger three (3) forests were investigated (Park W Niger, Wildlife Reserve of Tamou and the Gorou Bassounga forest while in Burkina Faso, five (5) forests were surveyed (classified forests of Saponé, Tiogo, Cassou, Laba and a section of Wildlife Reserve of Comoé-Léraba) (Figure 1). In Niger, the dominant soil texture is lateritic imbricated with silty-clayey and gravelly soil beaches with vegetation dominated by Tiger bush, shrub savannahs and grassy savannahs in the Sahelo-Sudanian and North Sudanian zones (Saadou, 1990). While in Burkina Faso, the dominant soil texture is silty-clay to sandy-silty with vegetation dominated by more or less shrubby tree savannahs (Thiombiano et al., 2006; Gaisberger et al., 2017). 


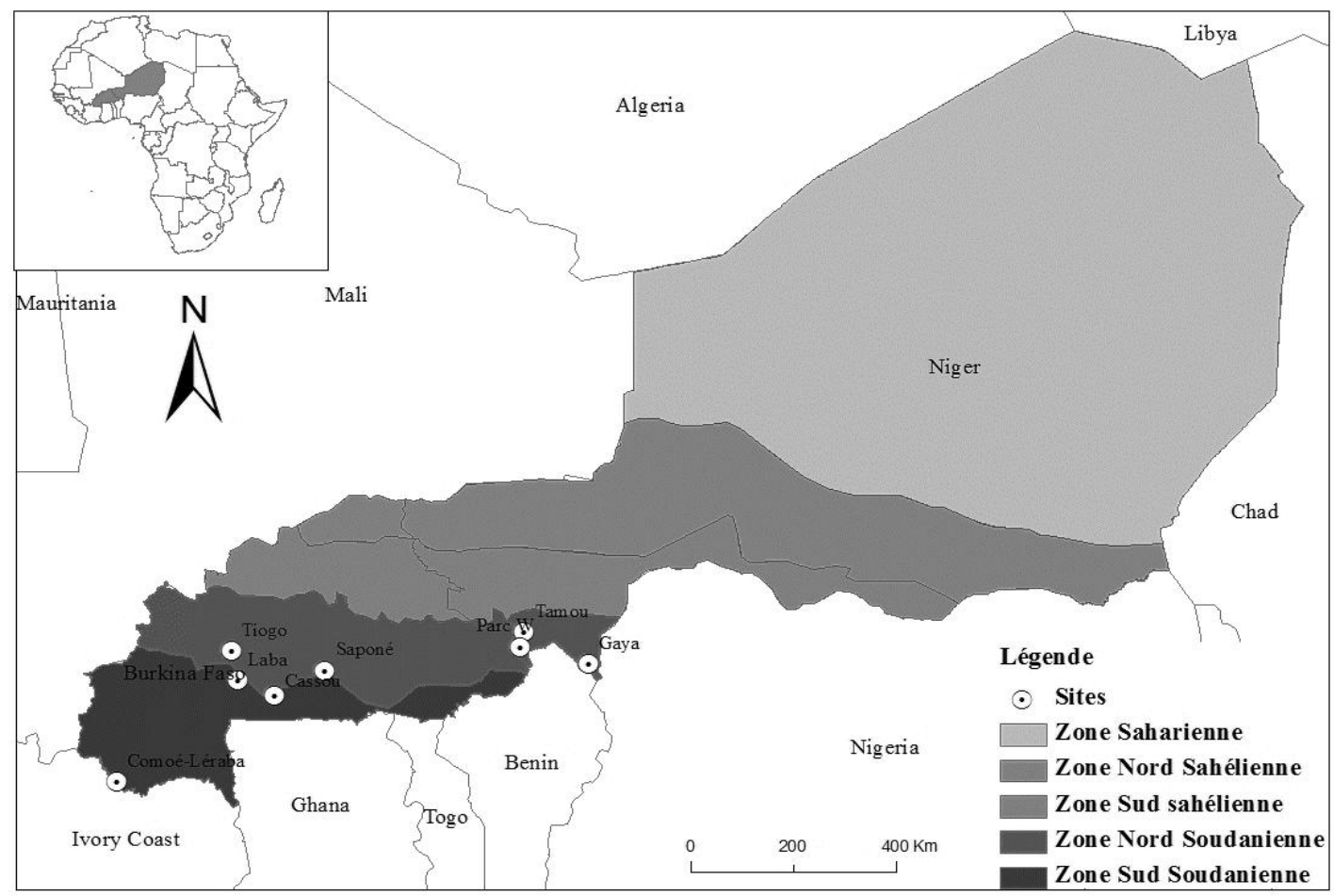

Fig.1. Location of study areas (Source: Rabiou et al., 2015)

Table 1. Characteristics of the surveyed sites

\begin{tabular}{|c|c|c|c|c|c|c|c|}
\hline \multirow{2}{*}{ Country } & \multirow{2}{*}{ Sites } & \multirow{2}{*}{$\begin{array}{c}\text { Agro- } \\
\text { ecological } \\
\text { zones }\end{array}$} & \multirow{2}{*}{$\begin{array}{l}\text { rainfall } \\
(\mathrm{mm} / \mathrm{an})\end{array}$} & \multirow{2}{*}{$\begin{array}{c}\text { Temperature } \\
\left({ }^{\circ} \mathrm{C}\right)\end{array}$} & \multirow{2}{*}{$\begin{array}{l}\text { Area } \\
(\text { ha })\end{array}$} & \multicolumn{2}{|c|}{ Geographical coordinates } \\
\hline & & & & & & Latitude & Longitude \\
\hline \multirow{3}{*}{ Niger } & Tamou & $\begin{array}{l}\text { Sahelo- } \\
\text { Sudanian }\end{array}$ & $606 \pm 99$ & $36,7^{\circ} \mathrm{C}$ & 76000 & $\begin{array}{l}12^{\circ} 28^{\prime} \text { and } \\
12^{\circ} 50^{\prime}\end{array}$ & $\begin{array}{l}2^{\circ} 06^{\prime} \text { and } \\
2^{\circ} 24^{\prime}\end{array}$ \\
\hline & Parc du W & $\begin{array}{l}\text { Sahelo- } \\
\text { Sudanian }\end{array}$ & $704 \pm 101$ & $30^{\circ} \mathrm{C}$ & 220000 & $\begin{array}{l}11^{\circ} 00^{\prime} \text { and } \\
12^{\circ} 35^{\prime}\end{array}$ & $\begin{array}{l}2^{\circ} 00 \text { and } \\
3^{\circ} 50^{\prime}\end{array}$ \\
\hline & GorouBassounga & $\begin{array}{l}\text { North } \\
\text { Sudanian }\end{array}$ & $740 \pm 119,5$ & $33^{\circ} \mathrm{C}$ & 9970 & $\begin{array}{l}11^{\circ} 52^{\prime} \text { and } \\
11^{\circ} 58^{\prime}\end{array}$ & $\begin{array}{l}3^{\circ} 20^{\prime} \text { and } \\
3^{\circ} 26^{\prime}\end{array}$ \\
\hline \multirow{5}{*}{$\begin{array}{c}\text { Burkina } \\
\text { Faso }\end{array}$} & Saponé & $\begin{array}{l}\text { North } \\
\text { Sudanian }\end{array}$ & $806 \pm 102$ & $26^{\circ} \mathrm{C}$ & 100 & $\begin{array}{l}12^{\circ} 07^{\prime} \text { and } \\
12^{\circ} 08^{\prime}\end{array}$ & $\begin{array}{l}1^{\circ} 33^{\prime} \text { and } \\
1^{\circ} 34^{\prime}\end{array}$ \\
\hline & Tiogo & $\begin{array}{l}\text { North } \\
\text { Sudanian }\end{array}$ & $827 \pm 169$ & $24^{\circ} \mathrm{C}$ & 30389 & $\begin{array}{l}12^{\circ} 11^{\prime} \text { and } \mathrm{t} \\
12^{\circ} 24^{\prime}\end{array}$ & $\begin{array}{l}2^{\circ} 39^{\prime} \text { and } \\
2^{\circ} 52^{\prime}\end{array}$ \\
\hline & Laba & $\begin{array}{l}\text { South } \\
\text { Sudanian }\end{array}$ & $907 \pm 157$ & $24^{\circ} \mathrm{C}$ & 18501 & $\begin{array}{l}11^{\circ} 48^{\prime} \text { and } \\
11^{\circ} 39^{\prime}\end{array}$ & $\begin{array}{l}2^{\circ} 44^{\prime} \text { and } \\
2^{\circ} 36^{\prime}\end{array}$ \\
\hline & Cassou & $\begin{array}{l}\text { South } \\
\text { Sudanian }\end{array}$ & $984 \pm 103$ & $29^{\circ} \mathrm{C}$ & 29515 & $\begin{array}{l}11^{\circ} 44^{\prime} \text { and } \\
11^{\circ} 21^{\prime}\end{array}$ & $\begin{array}{l}2^{\circ} 07^{\prime} \text { and } \\
1^{\circ} 44^{\prime}\end{array}$ \\
\hline & Comoé-Léraba & $\begin{array}{l}\text { Sudano- } \\
\text { Guinean }\end{array}$ & $1114,6 \pm 203$ & $27,4^{\circ} \mathrm{C}$ & 125000 & $\begin{array}{l}9^{\circ} 39^{\prime} \text { and } \\
10^{\circ} 00^{\prime}\end{array}$ & $\begin{array}{l}4^{\circ} 25^{\prime} \text { and } \\
4^{\circ} 59^{\prime}\end{array}$ \\
\hline
\end{tabular}

\section{Data collection and sampling}

We collected the vegetation data through random sampling transects method (Gounot, 1969) in eight (8) plant formations in Niger and Burkina Faso. We surveyed a total of 206 plots of $1000 \mathrm{~m}^{2}(20 \mathrm{~m} * 50 \mathrm{~m})$ established at each $300 \mathrm{~m}$ along 41 transects. The number of plots and transects vary from 20 to 42 and from 4 to 8 respectively 
(Table 2). In each plot, we measured all woody individuals with a diameter greater than or equal to $5 \mathrm{~cm}$ (Table 2).

Table 2. Number of transects and plots in all surveyed sites, ordered by decreasing latitude.

\begin{tabular}{llll}
\hline Agro-ecological zones & Sites & Number of transects & Number of plots \\
\hline \multirow{2}{*}{ Sahelian } & Tamou & 8 & 39 \\
\cline { 2 - 4 } & Parc W & 8 & 42 \\
\hline \multirow{2}{*}{ North Sudanian } & Gorou Bassounga & 4 & 20 \\
\cline { 2 - 4 } & Saponé & 4 & 20 \\
\cline { 2 - 4 } & Tiogo & 5 & 25 \\
\hline \multirow{2}{*}{ South Sudanian } & Laba & 4 & 20 \\
\cline { 2 - 4 } & Cassou & 4 & 20 \\
\hline Sudano-Guinean & Comoé-Léraba & 4 & 206 \\
\hline Total & & 41 & 20 \\
\hline
\end{tabular}

\section{Field measurements}

In each plot, $\mathrm{DBH}$, total height and two perpendicular crown diameters were measured for each recorded woody individual. These measurements were made using a forestry compass for large diameters, a calliper for small diameters, a tape measure, and a graduated pole for heights. For all individuals measured, a systematic count of young stems with a diameter less than $5 \mathrm{~cm}$, resulting from regeneration (sowing, stump sprouts, layers or suckering) was carried out. To collect tree regeneration data, we set five subplots of $5 \mathrm{~m} * 5 \mathrm{~m}\left(25 \mathrm{~m}^{2}\right)$ in each corner of the plot and a fifth in the center. In all surveyed sites, the dominant heights of young seedlings of all recorded species were systematically measured in accordance with the recommendations of SUN (2008). We recorded a total of 117 woody species in 207 plots carried out.

\section{Characteristics of inventoried species}

The biological type is a form of morpho-physiological adaptation of plants to unfavourable climatic conditions. The biological types of all recorded woody species were determined in accordance with the classification of Raunkiaer (1934) about woody phanerophyte vegetation. In fact, phanerophytes are woody plants whose buds are located more than $50 \mathrm{~cm}$ above the ground surface (Saadou, 1990). These include Nanophanerophytes ( $\mathrm{nPh}$ ) from 0.5 to $2 \mathrm{~m}$; Microphanerophytes $(\mathrm{mPh})$ from 2 to 8 $\mathrm{m}$; Mesophanerophytes (MesoPh) from 8 to $30 \mathrm{~m}$; Megaphanerophytes $(\mathrm{MPh})>30 \quad \mathrm{~m}$, Liana microphanerophytes ( $\mathrm{LmPh})$.

To determine the phytogeographic type of all recorded species we adopted the chorological subdivisions of White, (1983) that are being used (Mahamane et al., 2007; Osborne et al., 2018). Among these we have Cosmopolites (Cos) for species distributed in tropical and temperate regions of the world; African-American (AA) for species widespread in Africa and America; Pantropicals (Pan) concerning species widespread in Africa, America and tropical Asia; Paleotropical (Pal) that consists of species distributed in tropical Africa, tropical Asia, Madagascar and Australia; Afro-Malagasy tropical (AM) dedicated to species distributed in Africa and Madagascar; AfroTropicales (AT) for species widespread in tropical Africa; Pluri-regional (PA) that concern species whose range extends to several regional endemism centers; SoudanoZambéziennes (SZ) that encompass species distributed in both Sudanian and Zambezian regional endemism centers; all species distributed in the Guinean region belong to Guinean-Congolese (GC); and . Sudanian (S): for widely distributed species in the regional center for Sudanian endemism.

\section{Data analysis and processing}

\section{Alpha diversity indices}

In each site we calculated several parameters such as the specific richness, the specific diversity of Shannon (H') and the fairness of Piélou (E). These last two parameters provide information on the distribution of individuals of each species. Indeed, the higher the index the greater the diversity.

$$
H^{\prime}=-\sum_{i=1}^{s} p_{i} \log _{2} p_{i} \quad E=\frac{H^{\prime}}{\log _{2} S}
$$

with $\mathrm{S}=$ total number of species;

$\mathrm{pi}=(\mathrm{nj} / \mathrm{N})$, relative frequency of the species;

$\mathrm{nj}=$ relative frequency of species $\mathrm{j}$ in the sampling unit;

$\mathrm{N}=$ sum of the specific relative frequencies; 


\section{Typology of plant groups}

To identify a typology of plant groups, the species survey matrix was first subjected to an Ascending Hierarchical Classification (AHC) then to Non-Multidimensional Scaling analysis (NMDS) using PCord 5 software. These methods make it possible to summarize the information in the data table using dendrogram and factorial map.

The species with higher and statistically significant indicator values were considered to designate each group. However, since $P$. erinaceus was recorded in all relevés, therefore it will not be discriminating, and we removed it from the matrix before performing the analysis.

Sorensen index was calculated based on the number of common species between forest $\mathrm{A}$ and forest $\mathrm{B}$, the number of species of forest $A$ and the number of species of forest B. The index allows appreciating the level of similarity between two communities. It is calculated by the following formula:

$$
\text { IS }=2 c /(a+b)
$$

$\mathrm{c}=$ number of species common to $\mathrm{A}$ and $\mathrm{B}$ $\mathrm{a}=$ number of species of $\mathrm{A}$

$b=$ number of species of $B$

The index varies from 0 to 1 . When the index value is 1 , the level of similarity is perfect and when the index value is o 0 the two communities have no common species.

The data table on the raw spectrum frequencies of the phytogeographic types of the 8 forests investigated was subjected to a Principal Component Analysis (PCA).

\section{RESULTS}

\section{Floristic characteristics}

Our results show that Fabaceae was the dominant family in all surveyed sites with $31.8 \%$ followed by Combretaceae with $16.8 \%$. Malvaceae and Rubiaceae are represented by $7.9 \%$ and 6.9 respectively (Table 3 ). A total of 117 species were identified belong to 32 families. We observed the largest number of species (66 species) in the ComoéLéraba forest (Sudano-Guinean zone) while the lowest number (42 species) was in Tamou forest located in Sahelo-Sudanian zone.

Table 3. Frequency of families (\%) of surveyed sites

\begin{tabular}{lccccccccc}
\hline Familly & Parc W & Tamou & Gaya & Cassou & Comoé & Laba & Tiogo & Saponé & Global \\
\hline Fabaceae & 34.55 & 28.57 & 34 & 32.76 & 24.25 & 35.39 & 32.75 & 32.65 & 31.87 \\
Combretaceae & 20 & 19.05 & 14 & 17.24 & 16.67 & 13.85 & 17.24 & 16.33 & 16.80 \\
Malvaceae & 9.1 & 7.14 & 10 & 6.89 & 9.1 & 6.16 & 8.61 & 6.12 & 7.89 \\
Rubiaceae & 7.27 & 7.14 & 6 & 6.9 & 7.58 & 6.15 & 8.62 & 6.12 & 6.97 \\
Anacardiaceae & 3.64 & 9.52 & 8 & 5.17 & 3.03 & 7.69 & 6.9 & 8.16 & 6.51 \\
Capparidaceae & 7.27 & 9.52 & 4 & 0 & 0 & 4.62 & 3.45 & 2.04 & 3.86 \\
Euphorbiaceae & 1.82 & 2.38 & 2 & 3.45 & 3.03 & 4.62 & 3.45 & 2.04 & 2.85 \\
Apocynaceae & 0 & 0 & 4 & 3.45 & 1.52 & 3.08 & 3.45 & 2.04 & 2.19 \\
Meliaceae & 0 & 2.38 & 2 & 1.72 & 4.55 & 1.54 & 0 & 4.08 & 2.03 \\
Sapotaceae & 1.82 & 0 & 2 & 1.72 & 3.03 & 3.08 & 1.72 & 2.04 & 1.93 \\
Bignoniaceae & 3.64 & 2.38 & 2 & 1.72 & 1.52 & 0 & 1.72 & 2.04 & 1.88 \\
Olacaceae & 1.82 & 2.38 & 2 & 1.72 & 1.52 & 1.54 & 1.72 & 2.04 & 1.84 \\
Loganiaceae & 1.82 & 2.38 & 0 & 3.45 & 3.03 & 1.54 & 1.72 & 0 & 1.74 \\
Balanitaceae & 1.82 & 2.38 & 2 & 1.72 & 0 & 1.54 & 1.72 & 2.04 & 1.65 \\
Celastraceae & 1.82 & 0 & 0 & 1.72 & 1.52 & 1.54 & 1.72 & 2.04 & 1.30 \\
Ebenaceae & 1.82 & 0 & 0 & 1.72 & 1.52 & 1.54 & 1.72 & 2.04 & 1.30 \\
Annonaceae & 0 & 0 & 0 & 1.72 & 1.52 & 1.54 & 1.72 & 2.04 & 1.07 \\
Hymenocardiaceae & 0 & 0 & 2 & 1.72 & 1.52 & 0 & 0 & 2.04 & 0.91 \\
Moraceae & 0 & 0 & 2 & 0 & 3.03 & 0 & 0 & 2.04 & 0.88 \\
Rhamnaceae & 1.82 & 0 & 0 & 0 & 0 & 1.54 & 0 & 2.04 & 0.68 \\
Verbenaceae & 0 & 0 & 0 & 1.72 & 1.52 & 1.54 & 0 & 0 & 0.60 \\
\hline
\end{tabular}




\begin{tabular}{lccccccccc}
\hline Familly & Parc W & Tamou & Gaya & Cassou & Comoé & Laba & Tiogo & Saponé & Global \\
\hline Asclepiadaceae & 0 & 4.76 & 0 & 0 & 0 & 0 & 0 & 0 & 0.60 \\
Simaroubaceae & 0 & 0 & 2 & 1.72 & 0 & 0 & 0 & 0 & 0.47 \\
Flacourtiaceae & 0 & 0 & 2 & 0 & 1.52 & 0 & 0 & 0 & 0.44 \\
Chrysobalanaceae & 0 & 0 & 0 & 0 & 3.03 & 0 & 0 & 0 & 0.38 \\
Burseraceae & 0 & 0 & 0 & 0 & 0 & 0 & 1.72 & 0 & 0.22 \\
Polygalaceae & 0 & 0 & 0 & 1.72 & 0 & 0 & 0 & 0 & 0.22 \\
Sapindaceae & 0 & 0 & 0 & 0 & 0 & 1.54 & 0 & 0 & 0.19 \\
Araliaceae & 0 & 0 & 0 & 0 & 1.52 & 0 & 0 & 0 & 0.19 \\
Dipterocarpaceae & 0 & 0 & 0 & 0 & 1.52 & 0 & 0 & 0 & 0.19 \\
Myrtaceae & 0 & 0 & 0 & 0 & 1.52 & 0 & 0 & 0 & 0.19 \\
Opiliaceae & 0 & 0 & 0 & 0 & 1.52 & 0 & 0 & 0 & 0.19 \\
\hline Total & 100 & 100 & 100 & 100 & 100 & 100 & 100 & 100 & 100 \\
\hline
\end{tabular}

\section{Distribution of biological spectra of $P$. erinaceus formations}

The biological type that dominates all of the investigated forests is the microphanerophyte followed by nanophanerophyte both in terms of raw and weighted spectrum. Mesophanerophytes and microphanerophyte lianas are poorly represented in both the Sahelian and Sudanian zones (Table 4). The frequency of the raw spectrum of microphanerophyte lianas decreases from the Sahelian to the Sudanian zone. These are mainly Acacia erythrocalyx, Combretum aculeatum, Capparis tomentosa and Strophantus sarmentosus in the Sahelo-Sudanian zone and Opilia amentacea, Saba senegalensis, Baissea multiflora and Capparis sepiaria in the Sudanian zone. Our findings show also that the frequency of microphanerophytes increases from Sahelian to Sudanian zones, while nanophanerophytes decreases (Table 3). However, the $X^{2}$ test shows that the distribution of phytogeographic types is not related to the agroecological zones $($ Chi-Sq $=8.301 ; D F=9 ; P$-Value $=0.504)$.

Table 4. Biological type. LmPh :Liane microphanerophytes; $m P h:$ Microphanerophytes; $n P h:$ Nanophanerophytes ;

MesoPh: Mesophanerophytes.

\begin{tabular}{|c|c|c|c|c|c|c|c|c|}
\hline \multirow{2}{*}{ TB } & \multicolumn{2}{|c|}{ Sahelian } & \multicolumn{3}{|c|}{ North Sudanian } & \multicolumn{2}{|c|}{ South Soudanian } & \multirow{2}{*}{$\begin{array}{l}\text { SudanoGuinean } \\
\text { Comoé-Léraba }\end{array}$} \\
\hline & Tamou & Parc W & Gaya & Saponé & Tiogo & Laba & Cassou & \\
\hline \multicolumn{9}{|c|}{ Raw spectrum (\%) } \\
\hline$\overline{\mathrm{LmPh}}$ & 7.14 & 5.45 & 4 & 6.12 & 6.9 & 6.15 & 5.17 & 3.03 \\
\hline $\mathrm{MesoPh}$ & 2.38 & 3.64 & 4 & 2.04 & 1.72 & 1.54 & 1.72 & 6.06 \\
\hline $\mathrm{mPh}$ & 61.9 & 72.73 & 76 & 77.55 & 68.97 & 75.38 & 74.14 & 78.79 \\
\hline $\mathrm{nPh}$ & 28.57 & 18.18 & 16 & 14.29 & 22.41 & 16.92 & 18.97 & 12.12 \\
\hline Total & 100 & 100 & 100 & 100 & 100 & 100 & 100 & 100 \\
\hline \multicolumn{9}{|c|}{ Weighted spectrum (\%) } \\
\hline $\mathrm{LmPh}$ & 1.85 & 2.88 & 0.43 & 1.25 & 0.56 & 1.01 & 0.29 & 3.9 \\
\hline $\mathrm{MesoPh}$ & 0.03 & 0.06 & 0.18 & 1.17 & 0.14 & 0.11 & 0.25 & 1.28 \\
\hline $\mathrm{mPh}$ & 53.28 & 81.22 & 78.57 & 87.73 & 86.09 & 74.56 & 89.23 & 78.64 \\
\hline $\mathrm{nPh}$ & 44.84 & 15.83 & 20.81 & 9.84 & 13.21 & 24.31 & 10.23 & 16.17 \\
\hline Total & 100 & 100 & 100 & 100 & 100 & 100 & 100 & 100 \\
\hline
\end{tabular}




\section{Distribution of phytogeographic types}

The Principal Component Analysis PCA shows thatthe first two axes account respectively for 33.4 and $27.7 \%$ (both $61.1 \%$ ) of the variance. PCA results highlights forest groups according to agroecological zones. For instance Park $\mathrm{W}$ is distinguished by chorological characteristics much closer to the Sudanian areas. The Sahelo-Sudanian zone is characterized by a predominance of the Paleotropical (Pal) and Sahelo-Saharan (SS) species. The Guinea Congolian (GC), Sudanian (S) and Pantropical (Pt) species dominate the North Sudanian zone. The Southern Sudanian zone is distinguished by a predominance of Sudano-Guinean (SG), Afro-Malagasy (AM) and Afrotropical species (Figure 2).

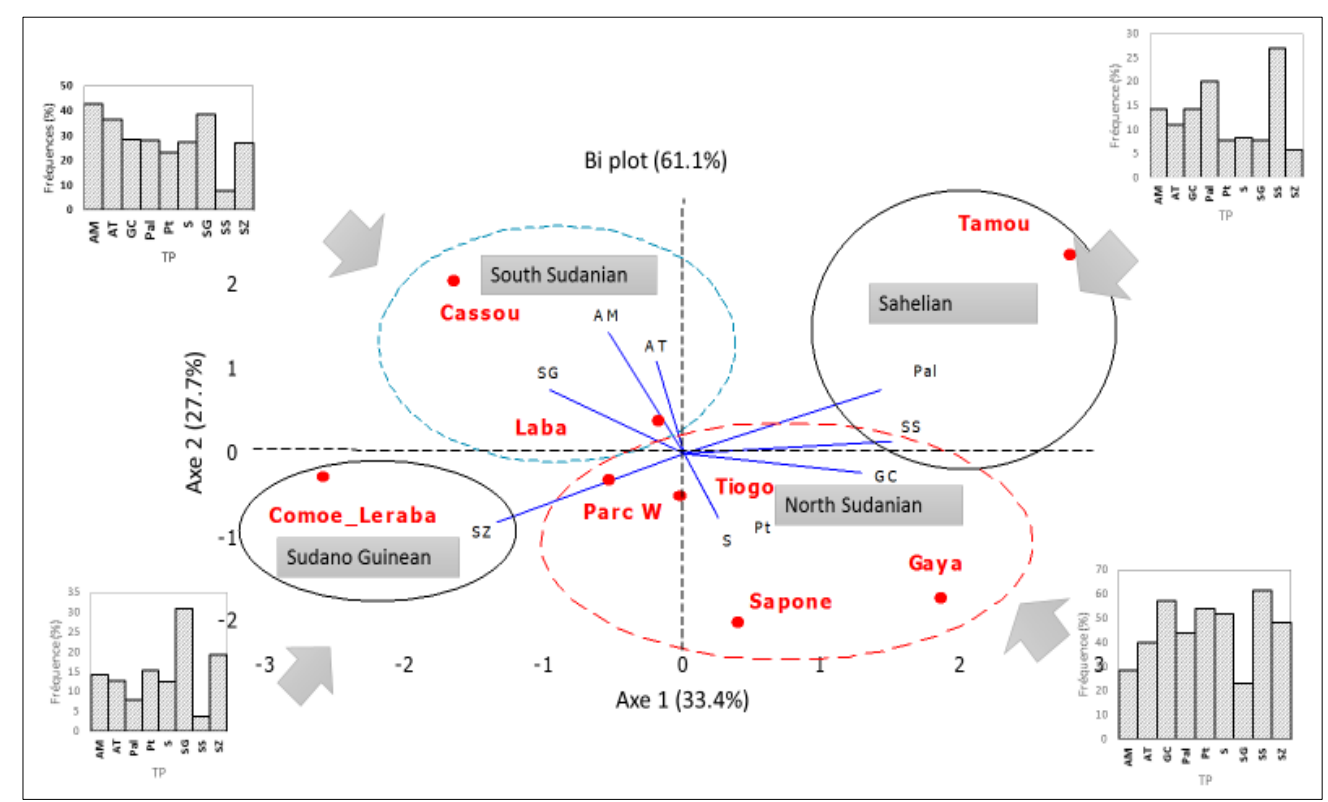

Fig.2. Distribution of biological types: AT: Afro-tropical; SG: Sudano-Guinean; AM: Afro-Malagasy; Pal: Paleotropical; SS: Sahelo-Saharan; GC: Guinean-Congolese; SZ: Sudano-Zambezian; S: Sudanian; Pt: Pantropical.

\section{Analysis of woody species diversity}

Analysis of the diversity indices reveals that the Tiogo and Comoé-Léraba forests are the most diversified as measured by Shannon diversity index which was 4.65 each one, although the species richness is greater in the ComoéLéraba forest with 66 species, against 58 species in the Tiogo forest. Indeed, Piélou's fairness is of 0.7 for each forest. The dominant species in the Comoé-Léraba forest is Terminalia mollis representing $14.6 \%$ of the woody individuals, while Combretum glutinosum is the dominant species in the Tiogo forest and represents $12.9 \%$ of the woody individuals. The lowest diversity is observed at the Tamou wildlife reserve with a richness of 42 species and a low fairness of 0.54 (Table 5). In this reserve, the dominant species is Guiera senegalensis and represents $37.5 \%$ of the woody species. The analysis of the specific contribution index in the achievement of the Shannon index $\left(2^{\mathrm{H}}\right)$ shows that in the Sahelo-Sudanian zone the dominance of certain species such as Guiera senegalensis and Combretum micranthum contributes largely to the weakness of the index. In Gaya and Tamou respectively only 9 and 8 woody species represent more than $90 \%$ of the stands. In the Sudanian zone where diversity is greater we observed up to 25 species representing $90 \%$ of the woody species.

Analysis of the diversity indices indicates that diversity is a function of humidity. The more watered sites recorded the large diversity of species due to the significant richness and fairness, suggesting a lack of pronounced dominance of certain species. In the Sahelian zone, the dominance of Combretaceae, in particular Guiera senegalensis, Combretum nigricans and Combretum micranthum, considerably reduces the Shannon diversity index, resulting in poor fairness. The Shannon diversity index and the species richness increase from the Sahelo-Sudanian to the Sudano-Guinean zone (Table 5).

Analysis of the species rarefaction curve shows that the accumulation of species richness is greater in the Sudanian and Guinean areas of Burkina Faso. Indeed, the high frequency of species observed in the Sahelo-Sudanian zone of Niger can be attributed to the high sampling effort. Figure 3 clearly indicates that for the same number of relevés, the cumulative variations in terms of species richness in the Sudanian and Guinean zones of Burkina Faso are clearly discriminated from those of the SaheloSudanian zones of Niger. For the same number of relevés, 
the number of species is only 31 at Parc W, 29 at Tamou and 51 at Tiogo.

Table 5. Diversity indices: Wealth (S), diversity (H') and Piélou equitability (E)

\begin{tabular}{lcccccccc}
\hline \multirow{2}{*}{$\begin{array}{l}\text { Diversity } \\
\text { indices }\end{array}$} & \multicolumn{2}{c}{ Sahelian } & \multicolumn{3}{c}{ North Sudanian } & \multicolumn{2}{c}{ South Sudanian } & Sudano Guiean \\
\cline { 2 - 8 } & Tamou & Parc W & Gaya & Saponé & Tiogo & Laba & Cassou & Comoé-Léraba \\
\hline $\mathrm{H}^{\prime}$ & 2.94 & 4.08 & 3.09 & 4.00 & 4.65 & 4.70 & 4.42 & 4.65 \\
$\mathrm{~S}$ & 42 & 55 & 50 & 49 & 58 & 65 & 58 & 66 \\
$\mathrm{H} \max$ & 5.39 & 5.78 & 5.64 & 5.61 & 5.86 & 6.02 & 5.86 & 6.04 \\
$\mathrm{E}$ & 0.54 & 0.71 & 0.55 & 0.71 & 0.79 & 0.78 & 0.75 & 0.77 \\
$2^{\mathrm{H}}$ & 7.65 & 16.80 & 8.54 & 16.00 & 25.04 & 26.04 & 21.36 & 25.19 \\
\hline
\end{tabular}

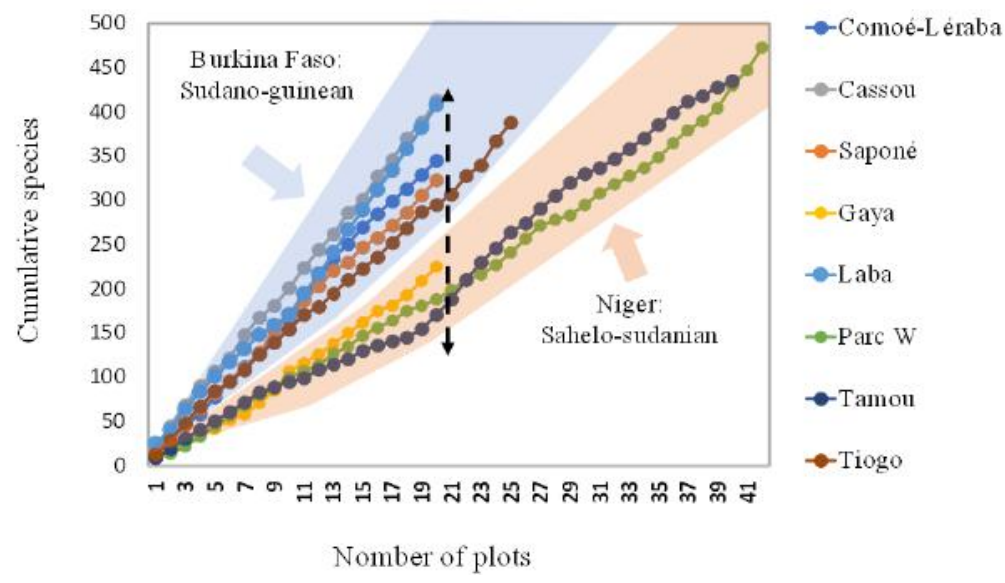

Fig.3. Species Curve of rarefaction and accumulation

\section{Sorensen's similarity index (Is)}

Analysis of the index shows that similarity is also a function of the rainfall gradient. Indeed, the sites located in the same agroecological zone have a higher level of similarity with higher Is indices. In the Sahelo-Sudanian zone, the level of similarity is of 0.66 between Park W and Tamou. In the northern Sudanian zone, the Is observed is 0.71 between Saponé and Tiogo. In the southern Sudanian zone, the index Is observed between Cassou and Laba is of 0.73 . However, the greatest similarity index was observed between Tiogo and Cassou although these two forests are belonging to different agroecological zones. While, the lowest similarity index is of 0.27 and was observed between the Tamou wildlife reserve (Sahelo-Sudanian zone) and the Comoé-Léraba wildlife reserve (SudanoGuinean zone) (Table 6).

Table 6. Values of the Sorensen Community index.

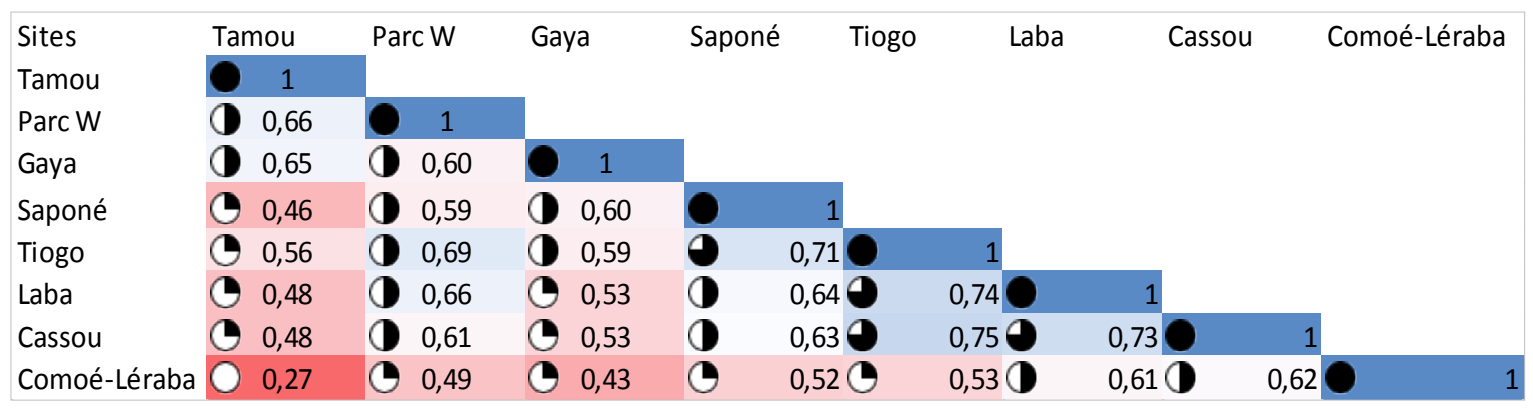

Legend: Evolution of the similarity index; from the highest index to the lowest (from blue to red)

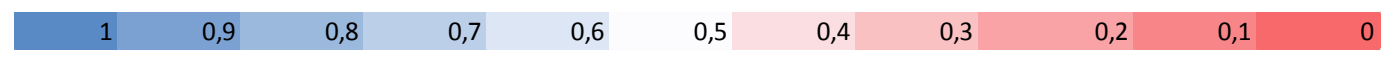




\section{Individualization of plant groups}

The CHA dendrogram made it possible to discriminate 6 plant communities with $P$. erinaceus. These communities vary according to agroecological zones at a threshold of proportion of the Similarity index (Figure 4) based on the Euclidean distance through the Ward method. Figure 4 shows by the position of the groups, the distance between them (if the distance between them is short, there is similarity and if it is long, it is dissimilarity). We found $35 \%$ of similarity that made it possible to determine 6 major groups distributed across the 4 different agroecological zones under study (Figure 5).

\section{$>$ Sahelo-Sudanian zone}

The Sahelo-Sudanian zone is made up of the Regional Park W (Niger) and a section of the Tamou wildlife reserve. In this area two large groups were observed.

- Sahelo-Sudanian zone (Sah 1): P. erinaceus and Combretum collinum

The group was mainly observed in Park W where we recorded many species with the highest indicator value at the 5\% threshold and statistically significant $(\mathrm{P}<0.05)$ such as Combrteum collinum Fresen., Anogeissus leiocarpa (DC.) Guill. and Perr., Lonchocarpus laxiflora Guill and Perr., Flueggea virosa (Roxb. ex Willd.) Voigt., Tamarindus indica L., Xeroderris stuhlamannii (Taub.) Mendonça and Sousa.

- Sahelo-Sudanian zone (Sah 2): P. erinaceus and Combretum nigricans

This grouping was largely noticed in Tamou. The indicator species with the significant indicator values $(\mathrm{P}<0.05)$ at the 5\% level are: Combretum nigricans Lepr. exGuill. And Perr., Acacia macrostachya Reicheb. Ex DC., Combretum micranthum G. Don, Guiera senegalensis J. F. Gmel., Feretia apodanthera Del., Acacia erhytrocalyx Brenan, Boscia senegalensis (Pers.) Lam. ex Poir., Boscia angustifolia A. Rich., Sclerocarya birrea Hochst., Combretum aculeatum Vent., Maerua angolensis DC., Dichrostachys cinerea (L.) Wight and Am., Strophanthus sarmentosus DC. and Cassia sieberiana DC ..

\section{$>$ Sudanian zone}

- North Sudanian zone (NS1): $P$. erinaceus and Gardenia sokotensis

This grouping is made up of surveys carried out in the North Sudanian zone particularly in (Gaya and the Wildlife Reserve of Tamou (Niger). The species with the highest indicator values are mainly, Gardenia sokotensis Hutch., Grewia flavescens Juss., Acacia laeta R. Br. Ex
Benth., GrewiabicolorJuss., Acacia nilotica (L.) Wild.Ex Del.And Gardenia erubescensStapf and Hutch.

- North Sudanian Zone (NS2): P. erinaceus and Combretum glutinosum

It is a group consisted mainly of surveys carried out in the North Sudanian Zone of Burkina Faso at Tiogo and Saponé sites. The species with large significant indicator values ( $\mathrm{P}<0.05)$ include Entada africana Guil. And Perr., Lannea microcarpa Engl. and K. Krause, Lannea vellutina A. Rich., Combretum glutinosum Perr. ex DC., Piliostigma reticulatum (DC.) Hochst., Acacia gourmaensis A. Chev., Ximenia americana L. and Parkia biglobosa (Jacq.) R. Br. ex G. Don f.

- South Sudanian zone (SS): P. erinaceus and Lannea acida

This group is made up of investigations carried out in the South Sudanian zone of Burkina Faso (Cassou and Laba). We recorded fifteen tree species with the largest indicator values. These include Lannea acida A. Rich., Crossopteryx febrifuga (G. Don) Benth., Detarium microcarpum Guill. et Perr., Combretum molle R. Br. ex G. Don, Annona senegalensis Pers., Strychnos spinosa Lam., Burkea africana Hook., Grewia mollis Juss., Bridellia ferruginea Benth., Pteleopsis suberosa Engl. and Diels., Terminalia avicennoides Guill. And Perr., Acacia dudgeon Craib. Ex Holl., Balanites aegyptiaca (L.) Del., Terminalia macroptera Guill. And Perr. And Vitex doniana Sweet.

\section{- Sudano-Guinean Zone (SG): P. erinaceus and Terminalia mollis}

In the Sudano-Guinean zone, only one plant community has been observed in the section of the Comoé-Léraba wildlife reserve. Nineteen significant indicator species $(\mathrm{P}$ $<0.001$ ) were recorded by Vitellria paradoxa C. F. Gaertn., Piliostigma thonningii (Schumach.) Milne-Redhead, Combretum fragrans F. Hoffm., Gardenia ternifolia Schum. \& Thonn., Maytenus senegalensis (Lam.) Exell, Terminalia laxiflora Engl. and Diels, Pericopsis laxiflora (Benth. ex Baker) Meeuwen, Daniella oliveri (Rolfe) Hutch. And Dalz., Terminalia mollis M. Laws., Maranthes polyandra (Benth.) Prance, Cussonia arborea Hochst. ex A. Rich, Opilia amentacea Roxb, Parinari curatellifolia Planch. Ex Benth, Gardenia aqualla Stapf and Hutch., Saba senegalensis (A.DC.) Pichon, Diospyros mespiliformis Hochst.ex A. DC., Syzgium guineense (Wild.) DC., Khaya senegalensis (Desr.) A. Juss. And Isoberlinia doka Craib and Stapf .. 


\begin{tabular}{|c|}
\hline Sudano-Guinean \\
Comoé-Léraba \\
Terminalia mollis \\
\hline South Sudanese \\
Cassou et Laba \\
Lannea acida \\
\hline
\end{tabular}

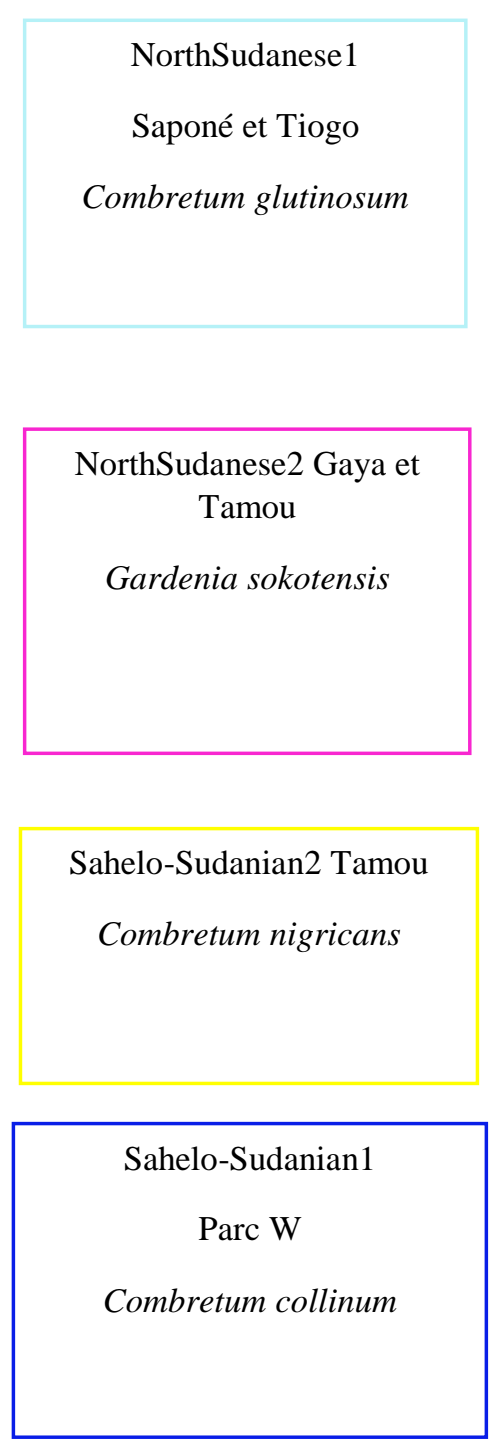

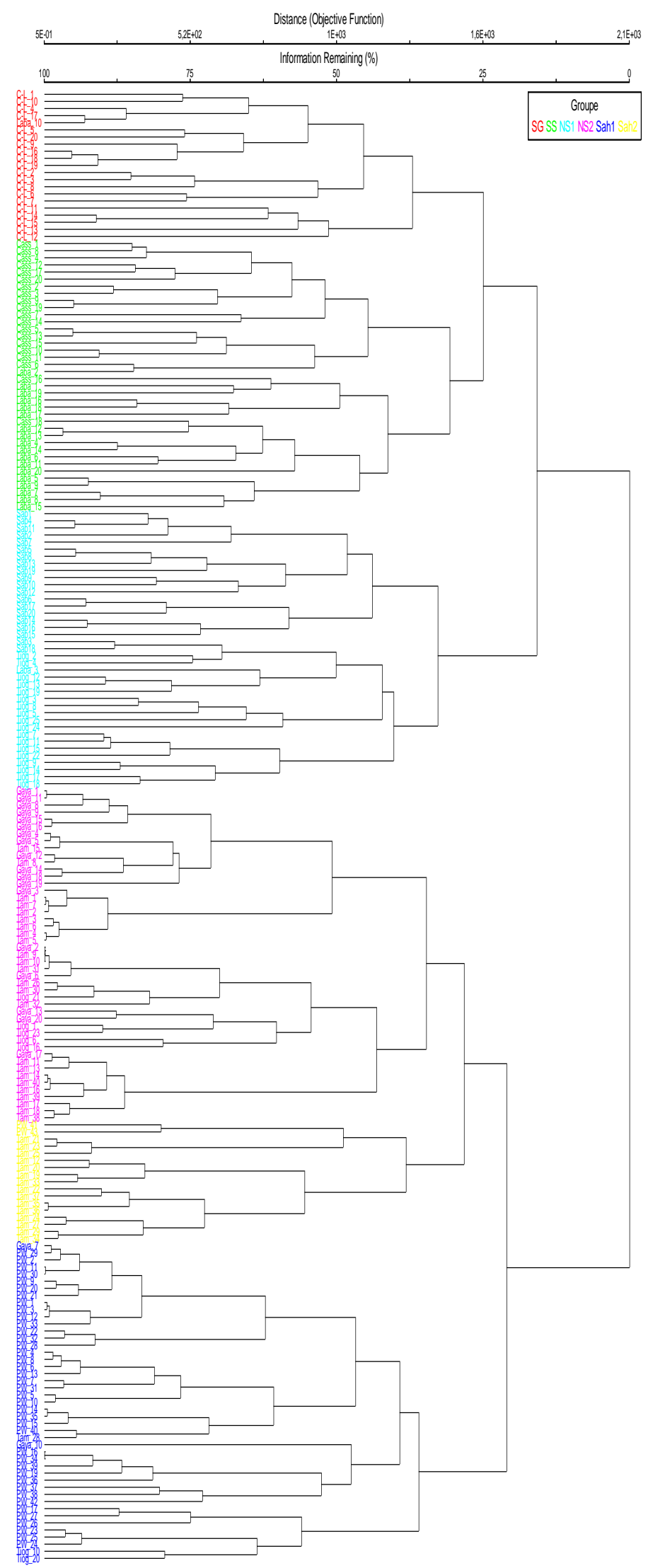

Fig.4. Distribution of relevés according to their similarity 


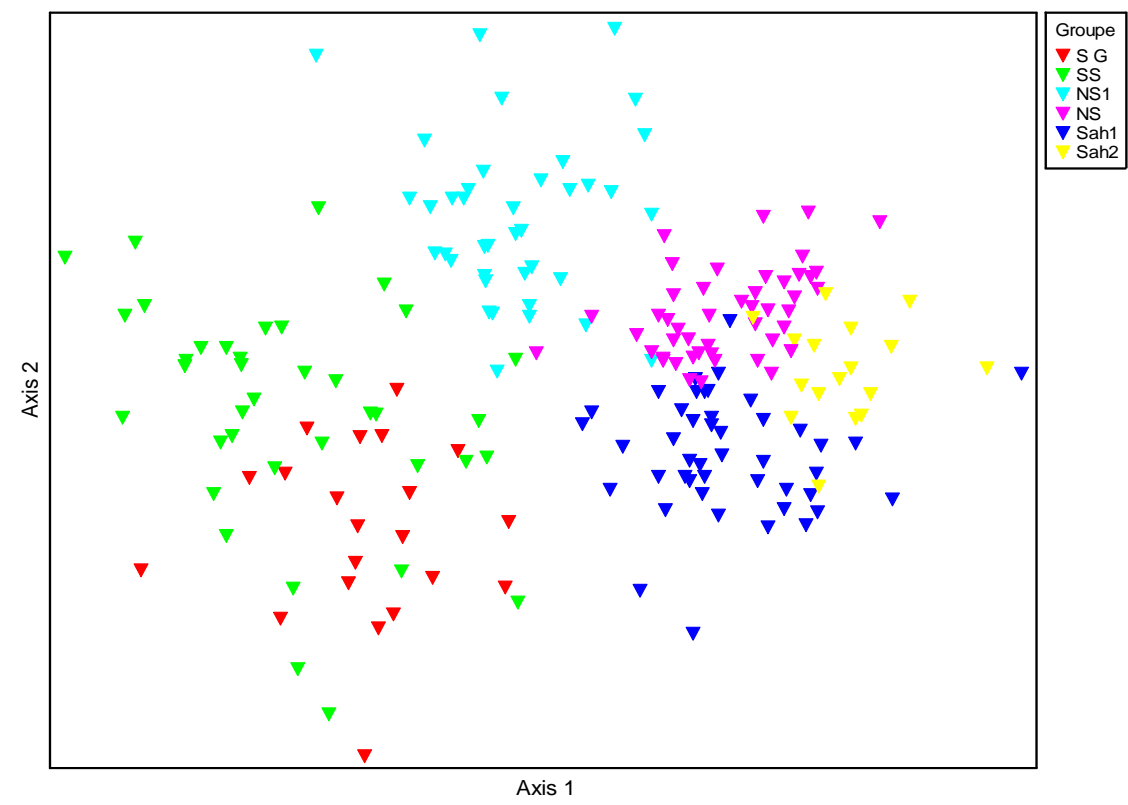

Fig.5. Representation of the distribution relevés using Non-Multidimensional Scaling (NMDS)

\section{DISCUSSION}

The analysis of the floristic characteristics of all investigated agroecological zones showed a predominance of species belonging to 4 families classified according to their importance respectively Fabaceae, Combretaceae, Malvaceae and Rubiaceae. The distribution of these families varies according to agroecological zones. Ouédraogo et al. (2006) findings on the diversity of woody species in the eastern part of Burkina Faso showed the predominance of these families in the same agroecological zones. Moreover, the predominance of Combretaceae followed by Mimosaceae in the Sahelo-Sudanian zone has also been reported by several authors such as Diouf et al. 2010) in W park in Niger and Oborne et al. (2018) when studying the human impacts and the adaptation of the plant functional traits of African savannah. The decrease in frequencies of Combretaceae with increasing humidity could be explained by the decrease in xerophytic characteristics of the vegetation. According to Aubreville (1950), the predominance of the Combretaceae family is an indicator of a generally dry climate. On the other hand, the frequency of Caesalpiniaceae, which increases with increasing humidity, indicates a decrease in aridity from the Sahelian to the Sudanian zone. Numerous studies have shown that in the wetlands of West Africa the dominant taxa are gregarious Caesalpiniaceae (White, 1983; Osborne et al., 2018). The diversity analysis showed that the Shannon diversity, the Piélou fairness and species richness indices increase with the humidity gradient. Indeed, the dominance of one or two species is very marked in the driest areas and decreases with increasing humidity. Thus, in the Sahelian zones, notably at Tamou and Parc W, the dominant species are Guiera senegalensis, Combretum micranthum and Combretum nigricans. The regeneration of these species, according to Diouf et al. (2010) is mainly achieved through vegetative propagation. This type of regeneration, comprising several forms such as layering, suckering and stump sprouts (Bationo et al., 2005), is carried out using lying stems or felled tree stumpor burnt trees. In the section of Comoé-Léraba wildlife reserve (Sudano-Guinean zone) the dominance of Terminalia mollis is not very pronounced (14.6\%) compared to the Tamou wildlife reserve where the dominant species (Guiera senegalensis) alone represents up to $37.5 \%$. This is confirmed by the Piélou (E) fairness index with 0.54 and 0.77 respectively for Tamou and Comoé-Léraba. Our findings have shown that species richness is also a function of the humidity gradient, thus confirming the results of Ouédraogo et al. (2006) who showed that the floristic richness of woody people increases from the Sahelian to the Sudanian zones. This highlights the influence of climate, notably rainfall, in the distribution of woody taxa (Osborne et al., 2018).

The vegetation surveys carried out allowed the determination of $P$. erinaceus groups. The distribution of the groups observed shows that $P$. erinaceus is much more associated with Combretaceae. In fact, in the SaheloSudanian zone two groups have been successfully discriminated. These are the P. erinaceus and Combretum collinum and Combretum nigricans groups in Parc W and Tamou respectively. These two contiguous plant formations recover the cuirass plateaus which appear in the 
form of large outcrops, resulting from the alteration of the sedimentary deposits of the Continental Terminal covering the bedrock (Diouf et al., 2010). The dominance of Combretumnigricans over these types of sedimentary soil has already been reported by Thiombiano et al. (2006). These authors have revealed that the species is abundant on clay-sandy or lateritic terrains in the Sahelo-Sudanian zone. In addition, the dominance of Combretum nigricans in these zones of cuirass plateaus can be explained by the particular characteristics of the vegetation. In fact, in these areas, the vegetation type is tiger bush and spotted bush characterised by alternating bare soil and strips of vegetation (thicket) (Diouf et al., 2010). The operating system of these arid zones is such that the runoff is concentrated in the center of the thicket. The microclimate thus created favors the installation of a dense vegetation network and even sensitive species such as $P$. erinaceus, Gardenia sokotensis and Combretum nigricans. The grouping of $P$. erinaceus and Combretum glutinosum observed in the forest of Tiogo, (northern Sudanian zone) has already been reported as a group dependent on slightly more humid and less hot zones (Thiombiano et al., 2006 ; Sanou et al., 2018). The frequency of Combretum glutinosum in the northern Sudanian zone is more than $70 \%$ (Ouédraodo et al., 2006). The grouping of $P$. erinaceus and Terminalia mollis was recorded in the wettest sites located in the Sudano-Guinean zone (the section of Comoé-Léraba). Gnoumou et al., (2015) findings indicated that in the Niangoloko forest located in the same zone, the grouping of Terminalia mollis of more than 100 ha in extent growing on low humus soils with pseudogley and weak surface acidity at the bottom of the valley. According to Thiombiano et al. (2006) and Schmidt et al. (2016) the latter species prefers the wettest sites in dry areas or areas with sufficient rainfall with an average rainfall of $1009 \pm 125 \mathrm{~mm}$, an average relative humidity of $56 \pm 3.4 \%$ and an average annual temperature of $28 \pm 0,6^{\circ} \mathrm{C}$.

\section{CONCLUSION}

Our study demonstrates that the largest number of species is observed in the Comoé-Léraba forest in the SudanoGuinean zone with 66 woody species and the lowest number is observed in the Sahelo-Sudanian zone in Tamou with 42 species. Overall the families mostly represented in all vegetation surveys carried out are Fabaceae, Combretaceae, Malvaceae and Rubiaceae. The diversity analysis shows that the Shannon index and the species richness increase with increasing rainfall. In fact, the Sahelo-Sudanian zone is dominated by Combretaceae, thus explaining the low recorded value of the Piélou fairness index. The study also made it possible to identify the $P$. erinaceus groupings in all the forests investigated, as well as the different phytogeographic and biological types which characterize these plant formations along the agroecological gradient. Our study reveals that $P$. erinaceus has great ecological amplitude and its distribution zone extends from the Sahelian to the Guinean zones while associating with a diversity of plant species. The high diversity of $P$. erinaceus habitat makes it complex the planning and management of the natural stands of this species.

\section{ACKNOWLEDGEMENTS}

The authors thank the West African Monetary Union (UMOA) for financial support.

\section{REFERENCES}

[1] Bationo B. A., Karim S. et Dourma M., 2005. Argumentaire pour l'étude et l'utilisation des marcottes et drageons dans les pays à faible couvert ligneux. AUF, sécheresse, volume $1 \mathrm{E}$, no3, $11 \mathrm{p}$.

[2] Chen Y., Yuan Z., Li P., Cao R., Jia H. and Ye Y., 2016.Effects of Environment and Space on Species Turnover of Woody Plants across Multiple Forest Dynamic Plots in East Asia. Front. Plant Sci. 7:1533. doi: 10.3389/fpls.2016.01533.

[3] Coulibaly A., Motelica-Heino M., Hien E., 2019.Determinants of Agroecological Practices Adoption in the Sudano-Sahelian Zone. Journal of Environmental Protection, $\quad 10, \quad 900-918$. https://doi.org/10.4236/jep.2019.107053

[4] Diouf A., Nicola B., Mahamane A., Lejoly J., Saadou M., Bogaert J., 2010. Caractérisation de la structure spatiale des individus ligneux dans une brousse tachetée au sud-ouest du Niger. CNRS. Rev. Can. Rach. For. Vol. 40 : 827-835.

[5] Gaisberger H., Kindt R., Loo J., Schmidt M., Bognounou F., Sylvestre D. S., Diallo O. B., Ganaba S., Gnoumo A., Lompo D., Lykke A. M., Mbayngone E., Nacoulma B. M. I., Ouedraogo M., Ouedraogo O., Parkouda C., Porembski S., Savadogo P., Thiombiano A., Zerbo G., Vinceti B., 2017. Spatially explicit multi-threat assessment of food tree species in Burkina Faso: A fine-scale approach. A fine-scale $\begin{array}{lllll}\text { approach.PLoS ONE } & 12 & \text { (9): } & \text { e0184457. }\end{array}$ https://doi.org/10.1371/journal.pone.0184457.

[6] Gnoumou A., Ouedraogo O., Schmidt M., Thiombiano A., 2015. Floristic diversity of classified forest and partial faunal reserve of Comoé-Léraba, southwest Burkina Faso. The journal of biodiversity data, Check List 11(1): 1557. doi:http://dx.doi.org/10.15560/11.1.1557.

[7] Gounot M., 1969. Méthodes d'étude quantitative de la végétation. Masson, Paris. 314 pp.

[8] Ligot G. Gourlet-Fleury S., Ou_Edraogo D.-Y., Morin X., Bauwens E. S, Baya F., Brostaux Y., Doucet J.-L., Fayolle A., 2018. The limited contribution of large trees to annual 
biomass production in an old-growth tropical forest. Ecological Applications, 0(0), pp. 1-9.

[9] LoubotaPanzou G. J., Ligot G., GourletFleury S., Doucet J. L., Forni E., Loumeto J. J., Fayolle A., 2018. Architectural differences associated with functional traits among 45 coexisting tree species in Central Africa. Functional Ecology.1-11. DOI: 10.1111/1365-2435.13198.

[10] LoubotaPanzoua G. J., Fayolle A., Feldpausch T. R., Ligot G., Douceta J.-L., Fornid E., Zombo I., Mazengue M., Loumeto J.-J., Gourlet-Fleuryd S., 2018. What controls local-scale aboveground biomass variation in central Africa? Testing structural, composition and architectural attributes. Forest Ecology and Management 429: 570-578. https://doi.org/10.1016/j.foreco.2018.07.056.

[11] Mahamane A., Saadou M. et Lejoly J., 2007. Phénologie de quelques espèces ligneuses du Parc National du «W » (Niger), Sécheresse ; 18 (4) : 354- 358.

[12] Osborne C. P., Charles-Dominique T., Stevens N., John Bond W., Midgley G. F., Lehmann C., 2018. Human impacts in African savannahs are mediated by plant functional traits. New Phytologist, 220(1): 10-24. DOI:10.1111/nph.15236.

[13] Ouédraogo A., Adjima T., Hahn-Hadjali K., Guinko S. 2006. Diagnostic de l'état de dégradation des peuplements de quatre espèces ligneuses en zone soudanienne du Burkina Faso. Sécheresse, 17 (4): 485-491.

[14] Ouédraogo D.-Y., Doucet J.-L., Daïınou K., Baya F., Biwole A. B., Bourland N., Fétéké F., Gillet J.-F., Kouadio Y. L. Fayolle A., 2018. The size at reproduction of canopy tree species in central Africa. BIOTROPICA 50(3): 465-476. DOI: $10.1111 / b t p .12531$.

[15] Pennington R. T., Hughes M., Moonlight P. W., 2015. The Origins of Tropical Rainforest Hyperdiversity. Trends In Plant Sciences, CellPress, 20(11) : 693-695. http://dx.doi.org/10.1016/j.tplants.2015.10.005

[16] Rabiou H., Diouf A., Bationo B. A., Segla K. N., Mahamane A., Adjonou K., Kokou K., Kokutse A. D., Saadou M., 2015. Structure des peuplements naturels de Pterocarpuserinaceus dans le domaine soudanien, au Niger et au Burkina Faso. Bois et forêts des tropiques, 325 (3) : 71-83. DOI: https://doi.org/10.19182/bft2015.325.a31274

[17] Raunkiaer C., 1934. The life forms of plants and statistical plant geography. Clarendon, Oxford.

[18] Saadou M., 1990. La végétation des milieux drainés nigériens à l'Est du fleuve Niger. Thèse de Docteur ès Sciences Naturelles, Université de Niamey, 395 p. + annexes.

[19] Sanou L., Zida D., Savadogo P., Thiombiano A., 2018.Comparison of aboveground vegetation and soil seed bank composition at sites of different grazing intensity around a savannawoodland watering point in West Africa. Journal of Plant Research, Journal of Plant Research, 131, 773-788. https ://doi.org/10.1007/s1026 5-018-1048-3.

[20] Schmidt M., Mbayngone E., Bachmann Y., Hahn K., Zizka G., Thiombiano A., 2016. The impact of land use on species composition and habitat structure in Sudanian savannas - A modeling study in protected areas and agricultural lands of southeastern Burkina Faso. Candollea 71(2) : 265-274.
[21] Solefacka M. C. M., Fedoung E. F., Temgoua L. F., 2018. Factors determiningfloristic composition and functional diversity of plantcommunities of Mount Oku forests, Cameroon. Journal of Asia-Pacific Biodiversity, 11: 284293. https://doi.org/10.1016/j.japb.2018.03.005.

[22] Stevens N., Lehmann C. E. R., Murphy B. P., Durigan G., 2016. Savanna woody encroachment is widespread across three continents. Global Change Biology, 23(1): 235-244. doi: $10.1111 / \mathrm{gcb} .13409$.

[23] Thiombiano A., Schmidt M., Kreft H., Guinko S., 2006.Influence du gradient climatique sur la distribution des espèces de Combretaceae au Burkina Faso (Afrique de l'ouest). Jour. Inter. Botaniq. Syst. Candollea 61(1) : 189213.

[24] White F., 1983. La végétation de l'Afrique. Mémoire accompagnant la carte de végétation de l'Afrique. L'Organisation des Nations Unies pour l'Education, la Science et la Culture (UNESCO). 